\title{
Seroprevalence of hepatitis A virus according to age groups in Northern Anatolia of Turkey
}

\author{
Kuzey Anadolu'da yaş gruplarına göre hepatit A virüsünün seroprevalansı
}

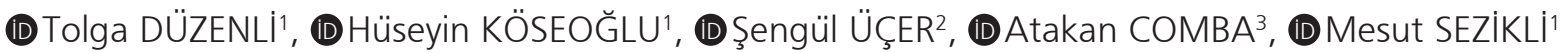 \\ Departments of ${ }^{1}$ Gastroenterology, ${ }^{2}$ Infectious Diseases and Clinical Microbiology and ${ }^{3}$ Pediatric Gastroenterology, Hitit University \\ Erol Olçok Training and Research Hospital, Çorum, Turkey
}

\begin{abstract}
Background and Aims: Hepatitis A virus is a cause of acute viral hepatitis that infects millions of people worldwide each year and maintains its prominence in both adults and in childhood. The aim of this study was to determine the hepatitis A seroprevalence in different age groups in Çorum which is the reference center for northern part of central Anatolia and to make recommendations for hepatitis A vaccine according to age groups. Materials and Methods: This retrospective study was conducted between January 2017 and January 2020. Patients tested for anti-hepatitis A virus for any reasons were enrolled from the data of all patients admitted to our hospital which is the reference center of the region. Serum samples were analyzed by ELISA. S/CO values of $\geq$ 1.00 were considered positive for anti-hepatitis $A$ virus immunoglobulin $G$ and immunoglobulin $M$, respectively; results below this value were considered negative. Anti hepatitis A virus immunoglobulin $G$ and anti-hepatitis $A$ virus immunoglobulin $M$ results of patients were analyzed according to age groups. Results: A total of 18817 anti-hepatitis A virus immunoglobulin $G$ and immunoglobulin $M$ assays were screened from the computerized database. 4244 assays were excluded for repeated tests from the same patients and inconclusive data. The study included 4115 patients with anti-hepatitis A virus immunoglobulin M and 10458 patients with anti-hepatitis A virus immunoglobulin G. Total anti-hepatitis $A$ virus immunoglobulin $G$ and $M$ positivities were $84.4 \%$ and $0.7 \%$. Anti-hepatitis A virus immunoglobulin $G$ prevalence was $85.8 \%$ and $83 \%$, and anti-hepatitis A virus immunoglobulin M positivity was $-0.98 \%$ and $0.38 \%$ in men and women. There was a significant difference in the prevalence of hepatitis $A$ virus immunoglobulin $G$ and immunoglobulin $M$ according to age groups in Çorum $(p<0.001, p=$ 0.035). Anti-hepatitis $A$ virus immunoglobulin $G$ seronegativity for 11 - 20 years of age was $28.4 \%$ and for 21 - 30 years of age was $24.2 \%$. Conclusion: This study suggests that $11-20$ and $21-30$ years of age groups may be in the highest risk group for hepatitis $A$ virus infection with possible complications increasing with age, and this patient group constitutes the target population for vaccination.
\end{abstract}

Keywords: Hepatitis A virus infection, HAV, seroprevalence, age groups.

\section{INTRODUCTION}

Hepatitis A virus (HAV) is a non-enveloped, single-stranded RNA virus belonging to the family Picornaviridae. Its natural host is human. HAV is a cause of acute viral hepatitis that infects millions of people worldwide each year and maintains its prominence in both adults and in childho-

Correspondence: Tolga DÜZENLI

Hitit University Erol Olçok Training and Research Hospital, Department of Gastroenterology, Çepni, Inönü Street, P.K.:19040, Çorum, Turkey

Phone: +90 3642193000 • Fax: +90 3642193030 • E-mail: tolgaduzenli@yahoo.com
Giriş ve Amaç: Hepatit A virüsü, dünyada her yıl milyonlarca insanı enfekte eden, özellikle gelişmekte olan ülkelerde hem yetişkinlerde hem de çocuklukta önemini koruyan bir akut viral hepatit nedenidir. Bu çaIışmanın amacı, Türkiye'nin iç Anadolu Kuzey kesiminde referans merkezi olan Çorum'da farklı yaş gruplarındaki hepatit A seroprevalansını araştırmak ve bu yaş gruplarına göre hepatit A aşılaması konusunda öneriler yapmaktır. Gereç ve Yöntem: Çalışmaya Ocak 2017 - Ocak 2020 tarihleri arasında Hitit Üniversitesi Erol Olçok Eğitim ve Araştırma Hastanesi'ne herhangi bir nedenle başvuran ve anti-hepatit A virüsü testi yapılan tüm hastalar dahil edildi. Anti-hepatit $A$ virüsü immünglobulin $G$ ve immünglobulin M ELISA yöntemi ile analiz edildi ve $>1.00 \mathrm{~S} / \mathrm{CO}$ değerleri pozitif kabul edildi. Hastaların yaş gruplarına göre anti-hepatit $A$ virüsü immünglobulin $G$ ve anti-hepatit $A$ virüsü immünglobulin M sonuçları istatistiksel olarak araştırıldı. Bulgular: Retrospektif olarak toplam 18817 anti-hepatit A virüsü immünglobulin $G$ ve immünglobulin $M$ testi tarandı. 4244 sonuç, mükerrer istek oluşu veya eksik data nedeniyle çalışmadan çıkarıldı. Çalışmaya anti-hepatit A virüsü immünglobulin M'li 4115 hasta ve anti-hepatit A virüsü immünglobulin G'li 10458 hasta dahil edildi. Tüm gruptaki anti-hepatit A virüsü immünglobulin $G$ ve immünglobulin M pozitiflikleri sırasıly $\% 84.4$ ve $\% 0.7$ idi. Erkeklerde ve kadınlardaki anti-hepatit A virüsü immünglobulin $G$ prevalansı $\% 85.8$ ve $\% 83$ iken anti-hepatit A virüsü immünglobulin M pozitifliği \%0.98 ve $\% 0.38$ idi. Çorum'da yaş gruplarına göre hepatit A virüsü immünglobulin $G$ ve immünglobulin M prevalansları anlamlı farklılık göstermekteydi ( $p<0.001, p=0.035)$. Bölgemizde anti-hepatit $A$ virüsü immünglobulin G seronegativitesi 11 - 20 yaş için \%28.4 ve 21 - 30 yaş için \%24.2 idi. Sonuç: Bu çalışma, 11 - 20 ve 21 - 30 yaş gruplarının hepatit A virüsü enfeksiyonu açısından en yüksek risk grubunda olabileceğini düşündürmektedir. Hepatit A virüsü enfeksiyonu komplikasyonlarının yaşla beraber artışı nedeniyle, seronegatif genç erişkinlere hepatit A virüsü aşısı uygulanmalıdır.

Anahtar kelimeler: Hepatit A virüs enfeksiyonu, HAV, seroprevalans, yaş grupları.

od (1). An average of 1.5 million gets infected with HAV around the world every year (2). Transmission can mainly occur through fecal oral route, contaminated water or food consumption (3). The incidence of the disease is related to socio-economic status, hygienic conditions and

Düzenli T, Köseoğlu H, Üçer Ş, et al. Seroprevalence of hepatitis A virus according to age groups in Northern Anatolia of Turkey. The Turkish Journal of Academic Gastroenterology 2021;20:136-142. DOI: 10.17941/agd.1055281

Manuscript received: 27.06.2021 - Accepted: 17.12.2021 
access to clean water (4). While HAV infection is usually asymptomatic in the first years of life, as the age progresses, it becomes more severe. In the adult group, liver failure and mortality can reach up to $2 \%$ (2). For diagnosis, anti-HAV immunoglobulin (Ig) M antibody is used with a sensitivity and specificity of more than $99 \%$ (3). On the other hand, anti-HAV IgG antibodies indicate previous infection or vaccination and may remain positive for years (5).

With the implementation of vaccination programs and improvements in general hygiene conditions, the frequency of HAV reports is gradually decreasing, especially in childhood. However, the disease is currently reported frequently in endemic regions and maintains its importance in the adult age group, increased travel, mass migration and increased consumption of ready-made food. In our country, HAV seropositivity rates vary between regions. There is no study in the literature about hepatitis A seroprevalence in our region.

The aim of this study was to determine the hepatitis $A$ seroprevalence in different age groups in Çorum which is the reference center for northern part of central Anatolia, to compare it with the studies from different regions of Turkey and to make recommendations for hepatitis A vaccine according to age groups.

\section{MATERIALS and METHODS}

All patients who referred to Hitit University Erol Olçok Training and Research Hospital between January 2017 and January 2020 for any reasons and underwent anti-HAV tests were included in the study. Approval for the study was obtained from Hitit University Faculty of Medicine Local Ethics Committee with the decision number of 400/2021. In situations where the cases had more than one test, only the most recent test result were included in the study. Patients with repeated examinations and missing data were excluded from the study.

Anti-HAV IgG and IgM were analyzed by ELISA method (Architect i2000SR device and anti-HAV IgG and IgM kits/Abbott Diagnostics, Germany) in accordance with the manufacturer's recommendations. For both tests > $1.00 \mathrm{~S} / \mathrm{CO}$ values were considered positive. Anti-HAV IgG and anti-HAV IgM results were statistically analyzed according to the age groups of the patients.

Statistical analyzes were performed with SPSS v22 (SPSS, Chicago, IL, USA) statistical analysis program. In descriptive statistics, continuous data were determined as mean and standard deviation, and categorical data were determined as numbers and percentages. Chi-square $(\chi 2)$ test was used to detect anti-HAV IgG and IgM positivity according to gender and age groups. $p<0.05$ was considered statistically significant.

\section{RESULTS}

A total of 18817 anti-HAV IgG and IgM tests were screened from the hospital computer database. 4244 examinations were excluded due to repeating requests

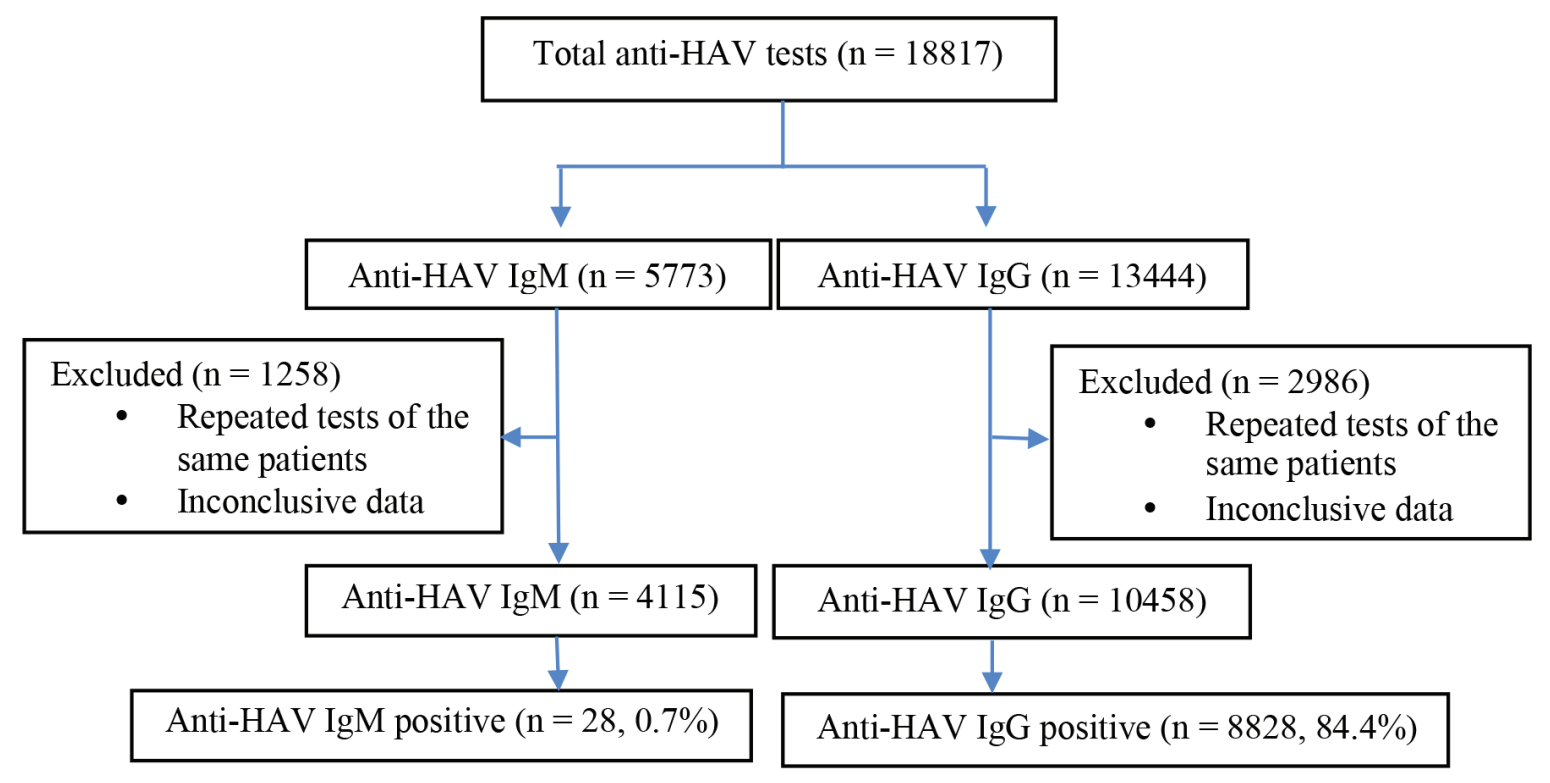

Figure 1. Patient enrollment and classification.

HAV: Hepatitis A virus, IgG: Immunoglobulin G, IgM: Immunoglobulin M, n: Number. 
and missing data. 4115 patients with anti-HAV IgM and 10458 patients with anti-HAV IgG were included in the study (Figure 1).

Anti-HAV IgG and IgM positivity in the whole study group were $84.4 \%$ and $0.7 \%$, respectively. Anti-HAV IgG prevalence in men and women were $85.8 \%$ and $83 \%$, while anti-HAV IgM positivity was $0.98 \%$ and $0.38 \%$. Anti-HAV IgG (Table 1) and anti-HAV IgM (Table 2) prevalence significantly differed according to age groups in Çorum $(p<$ $0.001, p=0.035)$.
The age groups with the lowest anti-HAV IgG positivity were 11 - 20 years (71.6\%) and 21-30 years (75.8\%). Anti-HAV IgG positivity rates were over $90 \%$ over the age of thirty (Figure 2). Anti-HAV IgG positivity rate in $0-10$ age group was higher with $84.6 \%$ compared to the $11-20$ age groups and $21-30$ age groups.

The highest rate of anti-HAV IgM positivity was in the 0 - 20 age group where $68 \%(n=19 / 28)$ of all cases were seen (Table 2).

Table 1. Seroprevalence of anti-HAV IgG for different age groups in Çorum, Turkey

\begin{tabular}{|c|c|c|c|c|c|}
\hline & \multicolumn{5}{|c|}{ Anti-HAV IgG } \\
\hline & & Negative $(n=1630)$ & Positive $(n=8828)$ & $\mathbf{p}$ & Total $(n=10458)$ \\
\hline \multirow{9}{*}{ Age group } & 0 - 10 years & $120(15.4 \%)$ & $659(84.6 \%)$ & & 779 \\
\hline & $11-20$ years & $581(28.4 \%)$ & $1463(71.6 \%)$ & & 2044 \\
\hline & 21 - 30 years & $629(24.2 \%)$ & $1970(75.8 \%)$ & & 2599 \\
\hline & 31 - 40 years & $155(8.9 \%)$ & $1586(91.1 \%)$ & $<0.001^{*}$ & 1741 \\
\hline & 41 - 50 years & $41(2.8 \%)$ & $1414(97.2 \%)$ & & 1455 \\
\hline & 51 - 60 years & $44(4.9 \%)$ & $851(95.1 \%)$ & & 895 \\
\hline & 61 - 70 years & $41(7.7 \%)$ & $489(92.3 \%)$ & & 530 \\
\hline & 71 - 80 years & $12(4.2 \%)$ & $274(95.8 \%)$ & & 286 \\
\hline & $>80$ years & $7(5.4 \%)$ & $122(95.6 \%)$ & & 129 \\
\hline
\end{tabular}

HAV: Hepatitis A virus, IgG: Immunoglobulin G, n: Number.

${ }^{*} p<0.05$ was considered statistically significant.

Table 2. Anti-HAV IgM positivity for different age groups in Çorum, Turkey

\begin{tabular}{|c|c|c|c|c|c|}
\hline & \multicolumn{5}{|c|}{ Anti-HAV IgM } \\
\hline & & Negative $(n=4087)$ & Positive $(n=28)$ & p & Total $(n=4115)$ \\
\hline \multirow{9}{*}{ Age group } & $0-10$ years & $558(98.4 \%)$ & $9(1.6 \%)$ & & 567 \\
\hline & $11-20$ years & $862(98.9 \%)$ & $10(1.1 \%)$ & & 872 \\
\hline & 21 - 30 years & $499(99.4 \%)$ & $3(0.6 \%)$ & & 502 \\
\hline & 31 - 40 years & 495 (99.4\%) & $3(0.6 \%)$ & $0.035^{\star}$ & 498 \\
\hline & 41 - 50 years & $472(99.8 \%)$ & $1(0.2 \%)$ & & 473 \\
\hline & 51 - 60 years & $450(100 \%)$ & $0(0 \%)$ & & 450 \\
\hline & $61-70$ years & 395 (99.7\%) & $1(0.3 \%)$ & & 396 \\
\hline & 71 - 80 years & $242(99.6 \%)$ & $1(0.4 \%)$ & & 243 \\
\hline & $>80$ years & $114(100 \%)$ & $0(0 \%)$ & & 114 \\
\hline
\end{tabular}

HAV hepatitis A virus, IgM: Immunoglobulin M, n: Number.

${ }^{*} p<0.05$ was considered statistically significant. P value of 0.035 represents that there was a significant difference in the prevalence of HAV IgM between the age groups. 


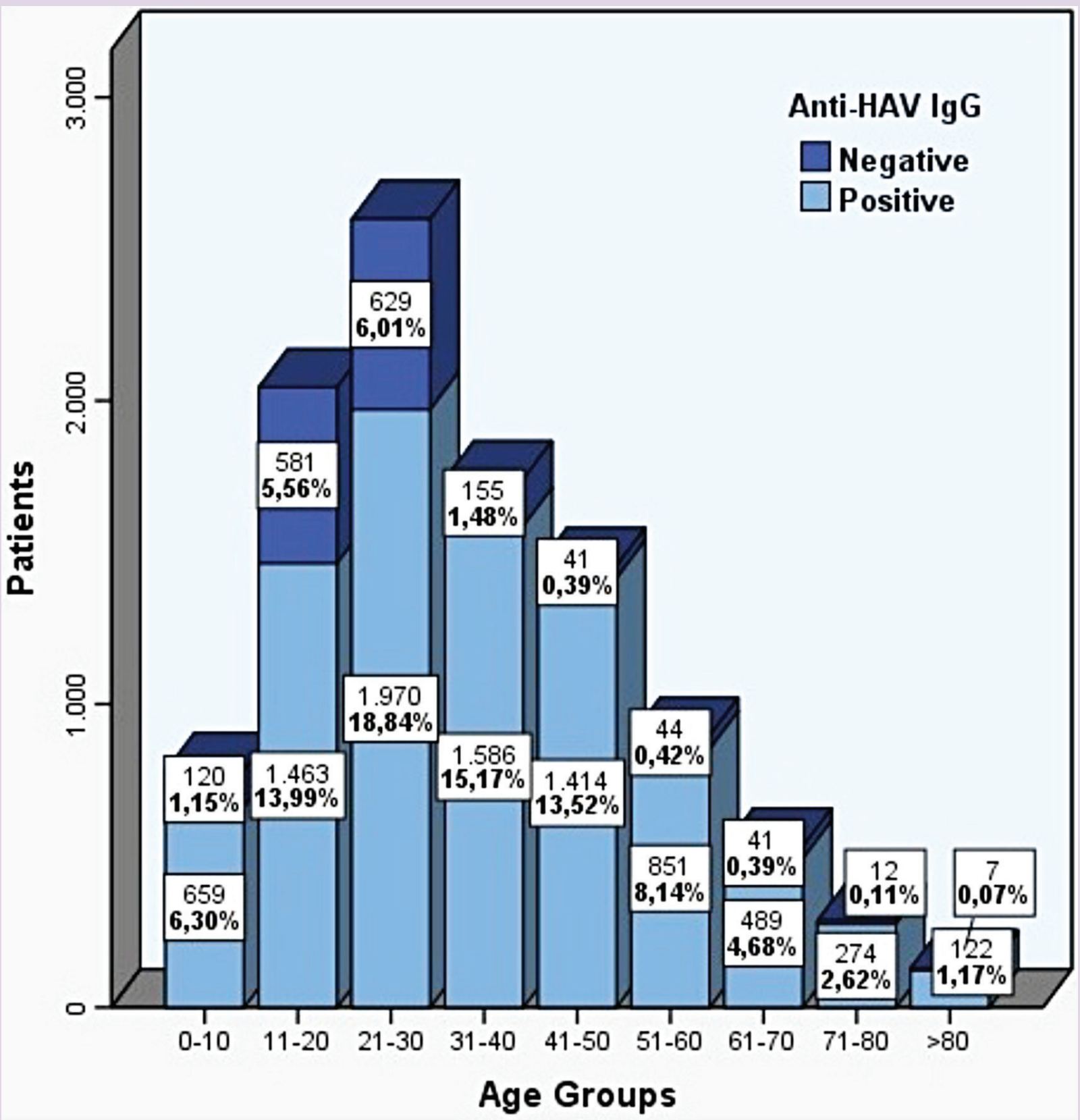

Figure 2. Graphical presentation of the seroprevalence of HAV IgG according to different age groups. HAV: Hepatitis A virus, IgG: Immunoglobulin G.

\section{DISCUSSION}

Hepatitis A is the most common cause for viral hepatitis (1). Today, the incidence of HAV infection is decreasing as a result of the age of contact with the virus, improvement in hygiene and sanitation conditions and shifting to an older age group where individuals become more susceptible to viral infection (6). Although the HAV mortality rate is low, HAV is considered as a public health issue that needs to be addressed due to outbreaks with labor loss (7). It is crucial to determine the change in the seroprevalence of the disease over the years for more successful detection of the preventive measures against HAV infection which maintains its importance in our society.

Acute HAV infection can be seen as sporadic or epidemic (1). There is no carrier for HAV in humans, but HAV can be detected in the feces of infected patients for more 
Table 3. Studies of seroprevalence of anti-HAV IgG of last 10 years in different age groups in Turkey.

\begin{tabular}{|c|c|c|c|c|}
\hline Study (Ref.) & Year & Province & Sample Size & Seropositivity Rate (\%) - Age groups \\
\hline Yılmaz (10) & 2020 & Erzurum & 25007 & $87.3 \%-0.2 \% ; 0-93$ years \\
\hline Kader et al. (11) & 2019 & Yozgat & 1862 & $79.1 \%$; > 6 years \\
\hline Çeviker et al. (14) & 2019 & Samsun & 2510 & $58.9 \% ;>0$ years \\
\hline Çalık et al. (12) & 2019 & İzmir & 1336 & $74 \%$; > 0 years \\
\hline Çavuş et al. (29) & 2018 & Bingöl & 897 & $97.4 \%$; > 16 years \\
\hline Karadeniz et al. (28) & 2016 & İstanbul & 3868 & $64.8 \% ; 1$ - 79 years \\
\hline Iraz et al. (26) & 2015 & İstanbul & 787 & $80 \%$; > 17 years \\
\hline Alhan et al. (15) & 2014 & Adana & 771 & $27.6 \% ; 2$ - 16.5 years \\
\hline Aşçı et al. (18) & 2014 & Afyon & 1458 & $69.7 \% ; 0$ - 57 years \\
\hline Dede et al. (16) & 2013 & Ankara & 1443 & $58 \% ; 1$ - 89 years \\
\hline Karaayak Uzun et al. (13) & 2013 & İzmir & 3887 & $85.2 \% ;>18$ years \\
\hline Kalem et al. (20) & 2013 & Konya & 12888 & $77 \% ; 0$ - 99 years \\
\hline Ceran et al. (17) & 2012 & İstanbul & 630 & $40 \% ; 5$ - 24years \\
\hline Ertürk et al. (19) & 2012 & Rize & 1112 & 75\%; 17 - 70 years \\
\hline Köroğlu et al. (21) & 2012 & Sakarya & 2003 & $74.7 \% ; 0$ - 92 years \\
\hline Karakaş et al. (27) & 2012 & Ankara & 392 & $86 \% ;>25$ years \\
\hline Türker et al. (22) & 2011 & Ankara & 4606 & $80.8 \% ;>0$ years \\
\hline Tosun et al. (23) & 2011 & 10 centers & & $91.1 \% ; 23-51$ years \\
\hline Çetinkol et al. (24) & 2011 & Ordu-Ünye & 728 & $57.9 \% ; 0$ - 50 years \\
\hline Altuntaş et al. (25) & 2011 & İstanbul-Haseki & & $91 \%$ \\
\hline
\end{tabular}

than six months. Improper sanitation conditions constitute the most important source of spread of HAV infection. Primary transmission occurs through the fecal oral route, close contact (especially domestic transmission), food and drink (3). Cases of transmission in injecting drug users, between male homosexuals and rarely with blood products have also been reported $(2,3)$.

HAV infection is divided into three endemicity groups as high, moderate and low according to their prevalence in the world (8). Due to socio-economic differences in various regions; Turkey-while showing a wide range of seroprevalence- is in the middle endemic region (8).

In our study, anti-HAV IgG and IgM positivity were determined as $84.4 \%$ and $0.7 \%$, respectively. Various studies conducted in our country shows that hepatitis $A$ is not only a childhood disease that adults are also susceptible (10-28). Especially in the west of Turkey, there is a seroepidemiological distribution similar to that in developed countries. On the other hand, since the development level of the eastern part of Turkey is lower than the development level of western part, seropositivity rate is higher in the eastern part $(10,30)$. The low incidence of hepatitis
A is explained by strong infrastructure, successful water sanitation and high hygiene awareness (28). According to the Ministry of Health's data, the incidence of acute viral hepatitis $A$ is decreasing over the years and regional differences are also decreasing. According to the data of 2017 from the General Directorate of Public Health, the incidence of hepatitis $A$ cases was found to be higher in Central Anatolia and Eastern Anatolia (31).

In the study conducted by Kader et al. in 2018 in Yozgat, in which they included patients over the age of 6 who were not vaccinated, they found the anti-HAV IgG rate as $79.1 \%(11)$. Karadeniz et al. reported that the total anti-HAV antibody prevalence was $64.8 \%$ in the Istanbul population (28). Çalık et al. reported that the seropositivity rate was $74 \%$ in Izmir (12) and Çavuş et al. reported 97.4\% (29) in Bingöl. In the study conducted by Yılmaz, covering 25007 tests, anti-HAV IgG and IgM positivity were found to be $87.3 \%$ and $0.2 \%$ in the Erzurum region in 2020 (10). Similar to our study, Y.lmaz determined the lowest anti-HAV IgG rates in adolescents and young adults. We think that the most important factor in these results is the hepatitis $A$ vaccination which started in 
2012 in Turkey (32). Currently in our country, hepatitis A vaccine is in the routine vaccination schedule and is administered to children in 2 doses at $18^{\text {th }}$ and $24^{\text {th }}$ months. In addition, HAV seronegative medical staff working in risky units are also vaccinated within the risk group.

According to the results of our study, while anti-HAV IgG positivity due to vaccination is high in children younger than ten years old, the rate of disease over the age of thirty is high. Supporting this finding, Akman et al. reported that anti-HAV IgG seronegativity shifted to adolescents due to vaccination $(6,33)$.

In terms of acute viral hepatitis A epidemiology, the rate was determined as $0.7 \%$ in our study. In recent studies in Turkey, rates were shown as $0.2-1.2 \%(10,13,19)$. In this context, the frequency of acute HAV infection in our area is consistent with the studies from Turkey. Similar to our study, Karacaer et al. reported that the incidence of acute HAV infection was higher especially in adolescence in which included 17 centers' data for the epidemiology of acute viral hepatitis (34). Çeviker et al. determined that complications due to acute hepatitis A were observed more frequently in adult ages (35). Considering that anti-HAV IgG seronegativity is $28.4 \%$ for 11 - 20 years

\section{REFERENCES}

1. Desai AN, Kim AY. Management of Hepatitis A in 2020-2021. JAMA 2020;324:383-4.

2. Franco E, Meleleo C, Serino L, Sorbara D, Zaratti L. Hepatitis A: Epidemiology and prevention in developing countries. World J Hepatol 2012;4:68-73

3. Ozaras R, Arends JE. Viral Hepatitis: Acute Hepatitis. Turse EP, Rassow B, Tahan V, editors. Cham, Switzerland: Springer Nature Switzerland AG; 2019. p. 17-24.

4. Jacobsen $\mathrm{KH}$, Wiersma ST. Hepatitis A virus seroprevalence by age and world region, 1990 and 2005. Vaccine 2010;28: 6653-7.

5. Koroglu M, Jacobsen KH, Demiray $\mathrm{T}$, et al. Socioeconomic indicators are strong predictors of hepatitis A seroprevalence rates in the Middle East and North Africa. J Infect Public Health 2017;10:513-7.

6. Demiray $T$, Köroğlu M, Jacobsen $\mathrm{KH}$, et al. Hepatitis A virus epidemiology in Turkey as universal childhood vaccination begins: seroprevalence and endemicity by region. Turk J Pediatr 2016;58:48091.

7. Word Health Organization (WHO). The global prevalence of hepatitis A virus infection and susceptibility: a systematic review: Geneva: World Health Organization; 2010 Contract No.: Document Number|. WHO/IVB/10.01. https://apps.who.int/iris/handle/10665/70180

8. Aggarwal R, Goel A. Hepatitis A: epidemiology in resource-poor countries. Curr Opin Infect Dis 2015; 8:488-96.

9. Yoldaş Ö, Bulut A, Altındiş M. The current approach of hepatitis A infections. Viral Hepat J 2012;18:81-6.

10. Yilmaz A. Hepatitis A seroprevalence in Erzurum, Turkey. Ann Agric Environ Med 2020;27:481-4 of age and 24.2 for 21 - 30 years of age in young adults in our region, we think that especially these age groups should primarily be evaluated in terms of HAV vaccination.

In our region, anti-HAV IgG seronegativity was $28.4 \%$ in 11 - 20 years of age and $24.2 \%$ in $21-30$ years of age, and was higher than the children under 10 years of agewho were vaccinated. Our study suggests that these age groups may be in the highest risk group for HAV infection. Since the complications of HAV infection increase with age, HAV vaccination should be recommended to seronegative young adults.

Ethics: This study was conducted in accordance with the Declaration of Helsinki. Ethics committee approval was received from Local Ethics Committee of Hitit University School of Medicine with the decision number of 400/2021.

Conflict of interest: The authors declare that there is no conflict of interest with regard to the authorship and/ or publication of this article.

Finance: The authors received no financial support for the research and/or authorship of this article.

11. Kader Ç, Göçmen AY, Demir MI, et al. Hepatitis A immunity in Yozgat, Turkey. Ann Saudi Med 2019;39:37-41.

12. Çalık Ş, Tosun S, Arı A, et al. [Hepatitis A seroprevalence in different age groups in a region with low and moderate socioeconomic level in Izmir province: results of a fieldwork]. Klimik Derg 2019;32:310-4.

13. Karaayak Uzun B, Hakan Er H, Gungor S, et al. Seroprevalence of hepatitis $A$ and hepatitis $E$ in adults patient admitted İzmir Katip Çelebi Universty Atatürk Training and Research Hospital. Viral Hepat J 2013;19:76-9.

14. Çeviker SA, Günal Ö, Kılıç SS, Köksal E, Tahmaz A. Samsun ilinde farklı yaş gruplarında hepatit A virüsü seroprevalansı. Balıkesir Sağlık Bilimleri Dergisi 2019;8:81-6.

15. Alhan E, Kozanoglu B, Tumgor G, et al. Epidemiological shift of hepatitis A in central Adana, Turkey. Turk J Gastroenterol 2014;25:6-8.

16. Dede A, Calıskan E, Biten Guven G, Cizmeci Z. Hepatitis a seropositivity in outpatients at Keçiören Teaching and Research Hospital. Viral Hepat J 2013;19:163-4.

17. Ceran N, Yuksel Kocdogan F, Mert D, et al. Hepatitis A seroprevalence in children and young adults in Istanbul, Turkey: seroprevalence change and associated factors. J Viral Hepat 2012;19:72-6.

18. Aşçı Z, Akgün S, Keşli R, Demirtürk N. Afyonkarahisar ilinde farklı yaş gruplarında hepatit A seroprevalansı. Göztepe Tıp Derg 2014;29:94-8.

19. Erturk A, Copur Cicek A, Cure E, Akdoğan RA, Ozturk Ç. Rize ilinde erişkin yaş gruplarında hepatit A aeroprevalansı. Viral Hepatit Dergisi 2013;19:85-8.

20. Kalem F, Erayman B, Yüksekkaya Ş, Kara F. Konya ilinde Hepatit A seroepidemiyolojisi. Viral Hepatit Dergisi 2013;19:19-22. 
21. Köroğlu M, Demiray T, Terzi HA, Altındiş M. Seroprevalence of Hepatitis A among Different Age Groups in Sakarya and Review of the Literature. Viral Hepat J 2014;20:110-4.

22. Türker K, Balcı E, Batı S, Hasçuhadar M, Savaş E. Ülkemizde hepatit A enfeksiyonunun değişen epidemiyolojisi. Türk Mikrobiyol Cem Derg 2011;41:143-8.

23. Tosun S, Yıldız O, Tekinkoruk S, et al. Kronik HBV ve HCV olgularıın HAV ile karşılaşma durumlarını yeterince değerlendiriyor muyuz? XI. Ulusal Viral Hepatit Kongre Kitabı. Antalya, 12-15 Nisan 2012;80-1.

24. Çetinkol $Y$, Altunçekiç $A$. Ünye Devlet Hastanesine başvuran hastalarda hepatit a seroprevalansı. Kocatepe Tıp Derg 2011;12:18-22.

25. Altuntaş AÖ, Kumbasar KH, Korkusuz R, Ataoğlu HE, Nazlıcan Ö. HIV/AIDS hastalarında HAV IgG seroprevalansı. XI. Ulusal Viral Hepatit Kongre Kitabı. Antalya, 12-15 Nisan 2012; 84-5.

26. Iraz M, Gültepe B, Doymaz MZ. Erişkin yaş gruplarında hepatit $A$ seroprevalansı. Abant Tıp Dergisi 2015;4:54-8.

27. Karakaş A, Coşkun O, Mert G, et al. Hepatit A seroprevalansında yedi yılda ne değişti?. XI. Ulusal Viral Hepatit Kongre Kitabı. Antalya, 12-15 Nisan 2012; 52.

28. Karadeniz A, Akduman Alaşehir E, Yeşilbağ Z, Balıkçı A, Yaman $G$. The seroprevalence of hepatitis A in Istanbul, Turkey. Marmara Med J 2017;30:14-7.
29. Çavuş B, Alagöz M, Gürkan Y. Evaluation of hepatitis A and isolated anti-Hbc IgG prevalences in A city of Eastern Anatolia. Arch Clin Biomed Res 2018;2:085-092

30. Koroglu M, Jacobsen KH, Demiray $T$, et al. Socioeconomic indicators are strong predictors of hepatitis A seroprevalence rates in the Middle East and North Africa. J Infect Public Health 2017;10:513-7.

31. Türkiye Viral Hepatit Önleme ve Kontrol Programı 2018-2023. Sağlık Bakanlığı Yayın No: 1102, Ankara, 2018.

32. Yüksek SK, Tezer H, Parlakay AÖ, et al. Impact of the mandatory hepatitis A immunization program: before and after the vaccine in Ankara, Central of Turkey. Turk J Pediatr 2019;61:677-85.

33. Akman AÖ, Burhan BY, Uzun AK, Taş D. Hepatitis A virus age-specific seroprevalence after the implementation of a Toddlers' Vaccination in Turkey: Shifting susceptibility to adolescents. Turk Pediatri Ars 2020;55:370-5.

34. Karacaer Z, Tosun S, Batırel A, et al. Changes in acute viral hepatitis epidemiology in the Turkish adult population: A multicenter study. Turk J Gastroenterol 2018;29:177-82.

35. Alkan Çeviker S, Günal Ö, Kılıç SS. Erişkin akut viral hepatit A olguIarının analizi. FLORA 2019;24:329-35. 